\title{
Role of inflammation in the hyperreactivity of the airways in asthma
}

Although asthma is usually diagnosed because of spontaneous and reversible attacks of bronchoconstriction, its most characteristic feature is the increased bronchial reactivity to a large variety of pharmacological and physical agents, such as histamine, methacholine, leukotrienes, prostaglandins, cold air, and dust. Thus asthmatic subjects develop a greater degree of bronchoconstriction from exposure to these stimuli than do subjects with normal bronchial reactivity. That this feature of asthmatic airways appears to have a fundamental role in the pathophysiology of asthma is supported by the observation that the severity of the disease correlates closely with the degree of hyperreactivity. ${ }^{1}$

The precise mechanism underlying the hyperreactivity of asthma is unknown. Whether this abnormality is inherent in the intrinsic property of airway smooth muscle or is at the level of its neural control remains unclear. The possibility that airways inflammation could be related to the development and maintenance of the bronchial hyperreactivity of asthma has been the subject of increasing research in recent years. Indeed, inflammation of the airways may create conditions that have themselves been proposed as possible mechanisms of hyperreactivity, such as bronchial oedema, mucosal hyperpermeability, exposure of epithelial sensory nerve endings, and release of inflammatory mediators. ${ }^{2}$ This article will review $(a)$ the recent experimental data linking the development of airways inflammation to the induction of airways hyperreactivity and $(b)$ the interactions between inflammatory cells and mediators that may be crucial in the pathophysiology of airways hyperreactivity.

\section{Airway inflammation in asthma}

The general features of an inflammatory response include vascular dilatation and increased vascular permeability with the formation of an exudate consisting of both plasma proteins and migrating inflammatory cells. Inflammatory reactions that affect mucous membranes such as those of the airways are also characterised by mucus hypersecretion

Address for reprint requests: Dr KF Chung, Department of Clinical Pharmacology, Cardiothoracic Institute, Brompton Hospital, London SW3 6HP. and shedding of the epithelial lining cells into the lumen. ${ }^{3}$ These features have been described in the airways of subjects dying of acute asthma, ${ }^{45}$ with an inflammatory cell infiltration consisting predominantly of eosinophils and appreciable epithelial cell loss, as shown by the denudation of the airway surface and by clumps of epithelial cells in sputum (Creola bodies). Although no detailed histological information of the airways of individuals with stable asthma is available, bronchoalveolar lavage of these subjects has shown that there are more eosinophils and neutrophils within the airway lumen than in normal subjects. ${ }^{67}$ Biopsies of the airway mucosa of asthmatic patients have confirmed the presence of epithelial cell damage, particularly of the ciliated cell type, ${ }^{8}$ and of the submucosal infiltration of eosinophils. ${ }^{9}$ A persistent low grade inflammatory response is therefore present in the airways of those with stable asthma.

\section{Relationship of acute inflammation to airways hyperreactivity}

One approach to evaluating the importance of inflammatory changes in asthma has been to examine the effect of inducing acute inflammation of the airways on reactivity of the airways. In several studies the presence of migrating cells such as eosinophils and neutrophils in the airways has been used as the sole index of inflammation, and the temporal relationship of the presence of these cells to the development of airways hyperreactivity has been examined. The effects of a wide range of inflammatory stimuli-for example, the atmospheric pollutant ozone, environmental antigens, and chemicals encountered at work, such as toluene diisocyanate- have been investigated in various species, including man.

\section{RESPONSE TO OZONE}

Exposure to ozone results in a transient increase in non-specific airways reactivity in the $\operatorname{dog},{ }^{10}$ the guinea pig, ${ }^{11}$ and man. ${ }^{12}$ In the dog the onset of hyperreactivity is coincident with the presence of neutrophil chemotaxis in the airway wall ${ }^{13}$ and with the recovery of increased numbers of neutrophils and desquamated epithelial cells in bronchoalveolar lavage fluid. ${ }^{14}$ Depletion of circulating neutrophils with hydroxyurea inhibits the hyperreactivity, 
implying that the neutrophil is an important effector cell in the response. ${ }^{15}$ Hydroxyurea may, however, have had effects on other cells apart from neutrophils. In man exposure to a lower concentration of ozone results in a more modest increase in reactivity to methacholine, an effect that is also associated with an influx of neutrophils in bronchoalveolar lavage fluid. ${ }^{16}$

Subsequent studies in the guinea pig have highlighted the species differences that exist in the response to the same stimulus, ozone. Neutrophil infiltration into the airways is absent during the phase of increased reactivity but occurs during the remission of hyperreactivity. ${ }^{17}$ A similar sequence of events was seen when guinea pigs were exposed to cigarette smoke $^{18}$; the hyperreactivity induced by this agent occurred during the phase of fluid and protein extravasation, associated with an increase in airways permeability, possibly resulting from disruption of epithelial tight junctions. ${ }^{19}$ The resulting increase in the exposure of epithelial sensory nerve fibres to inhaled substances could be a mechanism for hyperreactivity, as was first suggested for the exaggerated bronchomotor response resulting from upper respiratory tract infections. ${ }^{20}$ Guinea pigs exposed to ozone are, however, hyperreactive to inhaled as well as intravenous methacholine, ${ }^{11}$ and asthmatic patients with sustained hyperreactivity have normal respiratory mucosal permeability. ${ }^{21}$ In contrast to these studies of ozone and cigarette smoke, the hyperreactivity induced by toluene diisocyanate in the guinea pig coincides with the peak of neutrophil influx in the airway wall, ${ }^{22}$ suggesting not only species differences but also stimulus specificity with regard to the temporal sequence of hyperreactivity and the components of the inflammatory response.

\section{RESPONSE TO ANTIGEN}

Of greater relevance to asthma is the effect of responses mediated by immunoglobulin $\mathrm{E}(\mathrm{IgE})$ in sensitised subjects. A single inhalation of antigen in individuals with atopic asthma results in an early and late phase bronchonconstrictor response, and in a prolonged increase in airways reactivity that is associated with exacerbation of asthmatic symptoms ${ }^{\mathbf{2 3}}$; while avoidance of antigen over a period of two to three months improves asthma and results in a decrease in airways reactivity. ${ }^{24}$ The capacity of antigen for causing an inflammatory response in the skin of atopic subjects with an infiltration of mononuclear cells, neutrophils, and eosinophils has been well documented. ${ }^{25}$ In the ragweed sensitised dog and rabbit the development of airways hyperreactivity is temporally associated with an increased number of neutrophils in bronchoalveolar lavage fluid. ${ }^{2627}$ Only antigen challenged dogs with neutrophilia in the bronchoalveolar lavage fluid developed airways $\overrightarrow{\vec{F}}$ hyperreactivity. ${ }^{26}$ By contrast, in the asthmatic sub-듬 jects bronchoalveolar lavage fluid obtained during the late phase response to antigen has showed an increases in eosinophils and in the concentration of eosino $\mathbb{2}$ philic cationic protein, the latter reflecting eosinophip degranulation, ${ }^{28}$ although there were no significantchanges in numbers of neutrophils recovered. These asthmatic subjects with antigen induced late phase responses would have shown increases in reactivity, ${ }^{2}$ कू and therefore eosinophils may play a part in the pathophysiology of airways hyperreactivity ini asthma.

Putative role of inflammatory cells and mediators in airways hyperreactivity

The foregoing studies support the notion that inflammatory stimuli delivered to the airways activates cells within the airways ("primary effector cells") tơ release mediators that are chemotactic for cell ${ }^{\mathbb{Q}}$ derived from the circulation ("secondary effectop cells"). The precise role of these cells and of their" interactions remains to be defined, but these cells ande their mediators are potential modulators of airway\$ reactivity.

\section{PRIMARY EFFECTOR CELLS \\ Mast cells}

The mast cell has been proposed as the initiator of inflammatory responses to both allergic and non allergic stimuli in the airways. ${ }^{30}$ Although mast cellso are abundant in lung tissue, they form a relatively small proportion of the cells recovered from the lumen of the airways of normal and asthmatic subjects. ${ }^{71}$ It has been suggested that activation and degranulation of these relatively few intralumina mast cells leads to increased mucosal permeability ${ }_{i}^{\times}$ with subsequent activation of tissue mast cells. ${ }^{32}$ The mast cell releases a wide array of inflammatory mediators that may mimic some of the features of asthma including smooth muscle contraction and mucuso secretion. ${ }^{30}$ It also generates chemotactic factors for neutrophils and eosinophils, such as hydroxy eicosatetranoeic acid (HETE) and leukotriene B4. ${ }^{3033}$ The fact that 15-HETE generated fromos eosinophils ${ }^{34}$ and airway epithelial cells ${ }^{35}$ and majoin basic protein released from eosinophils can activate mediator release from mast cells ${ }^{3637}$ is an illustrations of the highly complex and interdependent roles of the different cell types present in inflamed airways.

\section{Alveolar macrophages}

Alveolar macrophages are in greater abundances within the airway lumen than are mast cells, and thexd also possess the capacity to generate chemotactic fac $\frac{\mathcal{P}}{\mathbb{P}}$ tors for eosinophils and neutrophils. ${ }^{3839}$ This may b尺 
achieved through the activation of their low affinity surface IgE receptors by antigen..$^{40}$ In addition, the capacity of alveolar macrophages for releasing platelet activating factor ${ }^{41}$ provides another mechanism for eosinophil chemotaxis into the airways because platelet activating factor (PAF) aerosolised into the airways of baboons causes eosinophilia in bronchoalveolar lavage fluid. ${ }^{42}$

\section{Epithelial cells}

The observation that in tracheal biopsy specimens from dogs exposed to ozone the concentration of migrating neutrophils was higher in the epithelial layer than in the subepithelium suggests that the airway epithelium could be a source of chemotactic factors for neutrophils. ${ }^{13}$ In the presence of arachidonic acid canine and human tracheal epithelial cells in vitro generate substantial amounts of 5-lipoxygenase $^{43}$ and 15-lipoxygenase metabolites, ${ }^{35}$ including leukotriene B4 and 8,15-di-HETE, which are both neutrophil chemotactic agents.

\section{SECONDARY EFFECTOR CELLS \\ Eosinophils and neutrophils}

The recruitment of the eosinophil in preference to the neutrophil to the human asthmatic airway when the chemotactic agents released by primary effector cells are active for both cell types remains to be explained. The infiltrating eosinophil can generate mediators that play a part in enhancing airways reactivity. Eosinophil cationic protein and major basic protein, both major components of eosinophilic granules, ${ }^{44}$ are cytotoxic to the respiratory epithelium ${ }^{45}$ and could therefore account for the denudation of the epithelium seen in asthma. ${ }^{46}$ Because airway epithelium elaborates a smooth muscle relaxant factor that remains to be identified, ${ }^{478}$ epithelial denudation may underlie the exaggerated response of the muscle to bronchoconstrictor substances. Eosinophils have the capacity to generate sulphidopeptide leukotrienes, notably leukotriene $\mathrm{C} 4,{ }^{49}$ and also the potent inflammatory mediator PAF. ${ }^{50}$ Although both mediators are potent bronchoconstrictors, only PAF has been reported to induce a transient increase in airways reactivity in several species, including the guinea pig, ${ }^{51}$ the dog, ${ }^{52}$ and man. ${ }^{53}$ Interestingly, PAF production is possibly enhanced through the interaction between the alveolar macrophage and the eosinophil, as more eosinophils are recruited through the generation of PAF by both cell types.

Although the neutrophil is less conspicuous than the eosinophil in the airway wall of asthmatic subjects, it is an extremely potent cell, capable of generating prostaglandins and thromboxane, leukotriene B4, and PAF; not surprisingly, it has been implicated in ozone induced and antigen induced hyperreactivity in dogs and rabbits respectively. ${ }^{1554}$ Supernatants from phagocytosing neutrophils in vitro may induce hyperreactivity when nebulised into the airways of rabbits but the responsible mediator has yet to be identified. $^{55}$

\section{Platelets}

A role for the platelet has also been suggested because platelet depletion prevented PAF induced airways hyperreactivity in guinea pigs, ${ }^{51}$ implying that this effect of PAF is mediated through the recruitment of platelets to the airways. After antigen inhalation challenge of asthmatic subjects platelets have been recovered in lavage fluid, ${ }^{56}$ and are activated in the circulation. ${ }^{57}$ The mechanism by which platelets may affect airway function remains to be elucidated, but the close apposition of these cells to airway smooth muscle in guinea pigs challenged with $\mathrm{PAF}^{58}$ suggests that they may have a direct effect, perhaps through the release of mediators. Platelets can also be primarily activated through an IgE dependent mechanism. ${ }^{59}$

\section{MEDIATORS OF AIRWAYS HYPERREACTIVITY}

The role of several mediators released during airway inflammation has already been mentioned. While some of these mediators, such as PAF, may induce airways hyperreactivity through the activation of intermediary cells, others-for example, the cyclooxygenase product prostaglandin $F_{2 a}{ }^{60}$-may act directly. Cyclo-oxygenase metabolites have been implicated in ozone induced hyperreactivity in dogs because it is blocked by indomethacin. ${ }^{61}$ This effect, however, is species dependent: in the guinea pig indomethacin had no effect but inhibition of the lipoxygenase pathway of arachidonic acid metabolism was effective. ${ }^{62}$ The role of cyclo-oxygenase and lipoxygenase products in the induction of hyperreactivity in man remains to be elucidated but the late phase bronchoconstrictor response after antigen challenge is known to be inhibited by indomethacin. ${ }^{63}$ Direct potentiation of airway smooth muscle contraction in vitro by inflammatory mediators, such as 5-HETE ${ }^{64}$ and leukotrienes C4 and D4, ${ }^{65}$ has been reported. Whether these effects are at the level of membrane binding or are due to changes in calcium fluxes remains to be determined. It seems unlikely that increases in the affinity of receptors or in their numbers explain hyperreactivity since this characteristic property of asthmatic airways occurs in response to a wide range of bronchoconstrictor agents in vivo. Because airway smooth muscle responsiveness in vitro of a group of subjects with wide ranging reactivities in vivo are similar, ${ }^{66}{ }^{67}$ it has been suggested that airways hyperreactivity may not result from an intrinsic abnormality of airway smooth muscle. These results, however, were obtained from patients with 
chronic obstructive airways disease but not from asthmatic patients.

Inflammatory mediators may also influence reactivity through neural mechanisms. Augmented release of acetylchuline from postganglionic nerve endings by serotonin ${ }^{68}$ or thromboxane $\mathrm{A}_{2}{ }^{69}$ has been suggested, but the failure of anticholinergic drugs to inhibit antigen induced hyperreactivity in man does not support this mechanism. ${ }^{70}$ Local axon reflexes may be sensitised after epithelial damage and local release of inflammatory mediators such as bradykinin, with the liberation of neuropeptides such as substance $P$; this could enhance the effect of other bronchoconstrictor substances. ${ }^{71}$ Finally, because several putative mediators in asthma can increase vascular permeability in the airways, ${ }^{72}$ the resulting oedema of the airway wall may theoretically contribute to the enhancement of airways reactivity through geometric factors. ${ }^{73}$

\section{Conclusion}

The interaction of inflammatory cells and mediators with airway smooth muscle and its neural control may form the basis for the exaggerated airway responses in asthma. The initial clinical and animal studies have been mainly descriptive, but they strongly suggest a role for inflammatory cells in altering airways reactivity. In vitro studies of these cells and of the mediators they generate have indicated several mechanisms by which airways hyperreactivity could occur. The initiating stimulus may determine the action of specific effector cells and cellular activation pathways in this process. Future research should be devoted to examination of the direct effect of inflammatory cells in the airways by experimental techniques already available. The mechanisms by which inflammation in the airways is maintained once it is initiated remain unclear; possibly the persistence of airways hyperreactivity in asthma results from a defect in the switching off of the inflammatory process. Further understanding of the basis for the airways hyperreactivity in asthma will depend on an interdisciplinary approach using the methods of physiology, pharmacology, biochemistry, and cell biology.

I thank Professor PJ Barnes for his constructive suggestions.

\section{References}

1 Juniper EF, Frith PA, Hargreave FE. Airway $\frac{}{0}$ responsiveness to histamine and methacholine: $\overline{\bar{c}}$ relationship to minimum treatment to control symp- $\widehat{\nabla}$ toms of asthma. Thorax 1981;36:575-9.

2 Boushey HA, Holtzman MJ, Sheller JR, Nadel JA. ® Bronchial hyperreactivity. Am Rev Respir Dis $\vec{\circ}$ 1980;121:389-413.

3 Florey H. Secretion of mucus in the inflammation of $\overrightarrow{\vec{\omega}}$ mucus membranes. In: Florey H, ed. General pathol- $\stackrel{\circ}{\circ}$ ogy. 3rd ed. London: Lloyd-Duke (Medical Books), $\vec{x}$ 1962:6.

4 Dunnill MS. The pathology of asthma with special refer- $\stackrel{\rightarrow}{\rightarrow}$ ence to changes in the bronchial mucosa. J Clin Pathol 0 1960;13:27-33.

5 Houston JC, de Nevasquez S, Trounce JR. A clinical and pathologic study of fatal cases of status asthmaticus. 음 Thorax 1953;8:207-13.

6 Godard P, Chaintreuil J, Damon M, et al. Functional $\mathcal{S}$ assessment of alveolar macrophages: comparison of $\mathbb{D}$ cells from asthmatics and normal subjects. $J$ Allergy Clin Immunol 1982;70:88-93.

7 Flint KC, Leung KBP, Hudspith BN, Brostoff J, Pearce $\stackrel{\mathbb{Q}}{-}$ FL, Johnson NM. Bronchoalveolar mast cells in $\vec{\varphi}$ extrinsic asthma: a mechanism for the initiation of $\infty$ antigen specific bronchoconstriction. $\mathrm{Br}$ Med $J$ ? 1985;291:923-6.

8 Laitinen LA, Heino M, Laitinen A, Kava T, Haahtela T. \& Damage of the airway epithelium and bronchial reactivity in patients with asthma. Am Rev Respir Dis 1985;131:599-606.

9 Glynn AA, Michaels L. Bronchial biopsy in chronic bronchitis and asthma. Thorax 1960;15:142-53.

10 Lee LY, Bleecker ER, Nadel JA. Effect of ozone on 3 bronchomotor response to inhaled histamine aerosol in dogs. J Appl Physiol 1977;43:626-31.

11 Roum J, Murlas C. Ozone-induced changes in muscarinic bronchial reactivity by different testing methods. J Appl Physiol 1984;57:1783-9.

12 Golden JA, Nadel JA, Boushey HA. Bronchial hyper irritability in healthy subjects after exposure to ozone. $\frac{3}{3}$ Am Rev Respir Dis 1978;118:287-94.

13 Holtzman MJ, Fabbri LM, O'Byrne PM, et al. Importance of airway inflammation for hyperresponsiveness induced by ozone. Am Rev Respir Dis 윽 1983;127:686-90.

14 Fabbri LM, Aizawa H, Alpert SE, et al. Airway hyperresponsiveness and changes of cell counts in bronchoalveolar lavage after ozone in dogs. Am Rev Respir Dis 1984;129:288-91.

15 O'Byrne PM, Walters EH, Gold BD, et al. Neutrophil depletion inhibits airway hyperresponsiveness induced $\omega$ by ozone exposure in dogs. Am Rev Respir Dis 1985;130:214-9.

16 Seltzer J, Bigby BG, Stulbarg M, et al. Ozone-induced $\frac{}{\widetilde{C}}$ change in bronchial reactivity to methacholine and? airway inflammation in human subjects. J Appl Physiol 1986;60:1321-6.

Department of Clinical Pharmacology Cardiothoracic Institute Brompton Hospital London SW3 $6 \mathrm{HP}$
17 Murlas CG, Roum JH. Sequence of pathologic changes $\frac{\vec{D}}{\mathbb{D}}$ in the airway mucosa of guinea pigs during ozone- $\frac{\rho}{D}$ induced bronchial hyperreactivity. Am Rev Respir Disळ 
1985;131:314-20.

18 Hulbert WM, McLean T, Hogg JC. The effect of acute airway inflammation on bronchial reactivity in guinea pigs. Am Rev Respir Dis 1985;132:7-11.

19 Hulbert WC, Walker DC, Jackson A, Hogg JC. Airway permeability to horseradish peroxidase in guinea pigs: the repair phase after injury by cigarette smoke. $A m$ Rev Respir Dis 1981;123:320-6.

20 Empey DW, Laitinen LA, Jacobs L, Gold WH, Nadel JA. Mechanisms of bronchial hyperreactivity in normal subjects after upper respiratory tract infections. Am Rev Respir Dis 1976;113:131-9.

21 Elwood RK, Kennedy S, Belzberg A, et al. Respiratory mucosal permeability in asthma. Am Rev Respir Dis 1983;128:N523-7.

22 Gordon T, Sheppard D, McDonald DM, Distefano S, Scypinski L. Airway hyperresponsiveness and inflammation induced by toluene diisocyanate in guinea-pigs. Am Rev Respir Dis 1985;132:1106-12.

23 Cockcroft DW, Ruffin RE, Dolovich J, Hargreave FE. Allergen-induced increase in non-allergic bronchial reactivity. Clin Allergy 1977;7:503-13.

24 Platts-Mills TAE, Mitchell EB, Nock P, Tovey ER, Moszoro H, Wilkins SR. Reduction of bronchial hyperreactivity during prolonged allergen avoidance. Lancet 1982;ii:675-7.

25 Solley GO, Gleich CJ, Jordan RE, Schroeter AL. The late phase of the immediate wheal and flare skin reaction. Its dependence upon IgE antibodies. J Clin Invest 1976;58:408-20.

26 Chung KF, Becker AB, Lazarus SC, Frick OL, Nadel JA, Gold WM. Antigen-induced airway hyperresponsiveness and pulmonary inflammation in allergic dogs. J Appl Physiol 1985;558:1347-53.

27 Marsh WR, Irvin CG, Murphy KR, Behrens BL, Larsen GL. Increases in airway reactivity to histamine and inflammatory cells in bronchoalveolar lavage after the late asthmatic response in an animal model. Am Rev Respir Dis 1985;131:875-9.

28 De Monchy JGR, Kauffman HF, Venge P, et al. Bronchoalveolar eosinophils during allergen-induced late asthmatic reactions. Am Rev Respir Dis 1985; 131:373-6.

29 Cartier A, Thomson NC, Frith PA, Roberts R, Hargreave FE. Allergen-induced increase in bronchial responsiveness to histamine: relationship to the late asthmatic response and change in airway calibre. J Allergy Clin Immunol 1982;70:170-7.

30 Casale TB, Kaliner MA. Allergic reactions in the respiratory tract. In: Bienenstock J, ed. Immunology of the lung and upper respiratory tract. New York: McGrawHill, 1984:326-44.

31 Tamioka M, Shiroh I, Shindon Y, Ishihara T, Takishima $T$. Mast cells in the bronchoalveolar lumen of patients with bronchial asthma. Am Rev Respir Dis 1984:129:1000-5.

32 Hogg JC. Bronchial mucosal permeability and its relationship to airway hyperreactivity. $J$ Allergy Clin Immunol 1981;67:421-6.

33 Robinson C, Holgate ST. Mast cell-dependent inflammatory mediators and their putative role in bronchial asthma. Clin Sci 1985;68:103-12.
34 Turk J, Maas RL, Brash AR, Roberts LJ, Oates JA. Arachidonic acid 15-lipoxygenase products from human eosinophils. J Biol Chem 1982;257:7086-76.

35 Hunter JA, Finkbeiner WE, Nadel JA, Goetzl EJ, Holtzman MJ. Predominant generation of 15-lipoxygenase metabolites of arachidonic acid by epithelial cells from human trachea. Proc Natl Acad Sci USA 1985;82:4633-7.

36 Goetzl EJ, Phillips MJ, Gold WM. Stimulus specificity of the generation of leukotrienes by dog mastocytoma cells. J Exp Med 1983;158:731-7.

37 O'Donnell MC, Ackerman SJ, Gleich CJ, Thomas LL. Activation of basophil and mast cell histamine release by eosinophil granule major basic protein. J Exp Med 1981;157:1981-91.

38 Gosset $\mathrm{P}$, Tonnel AB, Joseph M, et al. Secretion of a chemotactic factor for neutrophils and eosinophils by alveolar macrophages from asthmatic patients. J Allergy Clin Immunol 1984;74:827-34.

39 Hunninghake GW, Gallin II, Fauci AS. Immunologic reactivity of the lung. The in vivo and in vitro generation of a neutrophil chemotactic factor by alveolar macrophages. Am Rev Respir Dis 1978;117:15-23.

40 Joseph M, Tonnel AB, Tarpier G, Capron A. Involvement of immunoglobulin $\mathrm{E}$ in the secretory process of alveolar macrophages from asthmatic patients. J Clin Invest 1983;71:221-30.

41 Arnoux B, Duval D, Benveniste J. Release of plateletactivating factor (PAF-acether) from alveolar macrophages by the calcium ionophore A 23187 and phagocytosis. Eur J Clin Invest 1980;10:437-41.

42 Arnoux B, Denjean A, Page CP, Morley J, Benveniste J. Pulmonary effects of platelet-activating factor in a primate are inhibited by ketotifen [abstract]. Am Rev Respir Dis 1985;131:A2.

43 Holtzman MJ, Aizawa H, Nadel JA, Goetzl EJ. Selective generation of leukotriene B4 by tracheal epithelial cells from dogs. Biochem Biophys Res Commun 1983; 114:1071-6.

44 Ackerman SJ, Loegering DA, Venge P, et al. Distinctive cationic proteins of the eosinophilic granule: major basic protein, eosinophilic cationic protein and eosinophil-derived neurotoxin. J Immunol 1983;131: 2977-82.

45 Gleich GJ, Frigas E, Loegering DA, Wassom DL, Steinmuller D. Cytotoxic properties of the eosinophil major basic protein. J Immunol 1979;123:2925-7.

46 Filley WV, Holley KE, Kephart GM, Gleich GJ. Identification by immunofluorescence of eosinophil granule major basic protein in lung tissues of patients with bronchial asthma. Lancet 1982;ii:11-5.

47 Flavahan NA, Aarhus LL, Rimele TJ, Vanhoutte PM. Respiratory epithelium inhibits bronchial smooth muscle tone. J Appl Physiol 1985;58:834-8.

48 Barnes PJ, Cuss FMC, Palmer JBD. The effect of airway epithelium on smooth muscle contractility in bovine trachea. Br J Pharmacol 1985;86:685-91.

49 Weller PF, Lee CW, Foster DW, Corey EJ, Austen KF, Lewis RA. Generation and metabolism of 5-lipoxygenase pathway leukotrienes by human eosinophils: predominant production of leukotriene C4. Proc Natl Acad Sci USA 1983;80:7626-30. 
50 Lee TC, Lenihan DJ, Malone B, Roddy LL, Wasserman SI. Increased biosynthesis of platelet activating factor in activated human eosinophils. $J$ Biol Chem 1984;259:5526-30.

51 Mazzoni L, Morley J, Page CP, Sanjar S. Induction of airway hyper-reactivity by platelet activating factor in the guinea-pig. J Physiol 1985;365:107.

52 Chung KF, Aizawa H, Leikauf GD, Ueki IF, Evans TW, Nadel JA. Airway hyperresponsiveness induced by platelet-activating factor: role of thromboxane generation. J Pharmacol Exp Ther 1986;236:580-4.

53 Cuss FM, Dixon CM, Barnes PJ. Inhaled platelet activating factor in man: effects on pulmonary function and bronchial responsiveness. Lancet (in press).

54 Murphy KR, Irvin CG, Glezen LS, Marsh WR, Larsen GL. The effect of polymorphonuclear leukocyte depletion on the late asthmatic response and changes in airways reactivity [abstract]. Am Rev Respir Dis 1985;131:A6.

55 Irvin CG, Baltopoulos G, Henson P. Airways hyperreactivity produced by products from phagocytising neutrophils [abstract]. Am Rev Respir Dis 1985;131:A278.

56 Metzger WJ, Hunninghake GW, Richerson HB. Late asthmatic responses: inquiry into mechanisms and significance. Clin Rev Allergy 1985;3:145-65.

57 Knauer KA, Lichtenstein LM, Franklin Adkinson Jr N, Fish JE. Platelet activation during antigen-induced airway reactions in asthmatic subjects. $N$ Engl $J$ Med 1981;304:1404-7.

58 Lellouch-Tubiana A, Lefort J, Pirotzky E, Vargaftig BB, Pfister A. Ultrastructural evidence for extravascular platelet recruitment in the lung upon intravenous injection of platelet activating factor (Paf-acether) to guinea-pigs. Br J Exp Pathol 1985;66:345-55.

59 Joseph M, Auriault C, Capron A, Vorng H, Viens P. A new function for platelets: IgE-dependent killing of schistosomes. Nature 1983;303:310-2.

60 Walters EH, Parrish RW, Bevan C, Smith AP. Induction of bronchial hypersensitivity: evidence for a role of prostaglandins. Thorax 1981;36:571-4.

61 O`Byrne PM, Walters EH, Aizawa H, Fabbri LM, Holtzman MJ, Nadel JA. Indomethacin inhibits the airway hyperresponsiveness but not the neutrophil influx induced by ozone in dogs. Am Rev Respir Dis 1984;130:220-4.

62 Lee HK, Murlas C. Ozone-induced bronchial hyperreactivity in guinea-pigs is abolished by BW 755C or FPL 55712 but not by indomethacin. Am Rev Respir Dis 1985;132:1005-9.

63 Fairfax AJ, Hanson JM, Morley J. The late reaction following bronchial provocation with house dust mite allergen: dependence on arachidonic acid metabolism. Clin Exp Immunol 1983;52:393-8.

64 Copas JL, Borgeat P, Gardiner PJ. The actions of 5-,12and 15-HETE on tracheobronchial smooth muscle. Prostagland Leuk Med 1982;8:105-14.

65 Creese BR, Bach MK. Hyperreactivity of airways smooth muscle produced in vitro by leukotrienes. Prostagland Leuk Med 1983;11:161-9.

66 Vincenc KS, Black JL, Yan K, Armour CL, Donnelly PD, Woolcock AJ. Comparison of in vivo and in vitro responses to histamine in human airways. Am Rev Respir Dis 1983;128:875-9.

67 Armour CL, Lazar NM, Schellenberg RR, et al. A comparison of in vivo and in vitro human airway reactivity to histamine. Am Rev Respir Dis 1984;129:907-10.

68 Hahn HL, Wilson AG, Graf PD, Fischer SP, Nadel JA. Interaction between serotonin and efferent vagus nerves in dog lungs. J Appl Physiol 1978;44:144-9.

69 Chung KF, Evans TW, Graf PD, Nadel JA. Modulation of cholinergic neurotransmission in canine airways by thromboxane-mimetic U 46619. Eur J Pharmacol 1985;117:373-5.

70 Boulet LP, Latimer KM, Roberts RS, et al. The effect of atropine on allergen-induced increases in bronchial responsiveness to histamine. Am Rev Respir Dis 1984;130:368-72.

71 Barnes PJ. Asthma as an axon reflex. Lancet 1986; i:242-5.

72 Persson CGA, Svensjo E. Airway hyperreactivity and microvascular permeability to large molecules. Eur $J$ Respir Dis 1983;131:183-214.

73 Freedman BJ. The functional geometry of the bronchi. The relationship between changes in external diameter and calibre, and a consideration of the passive role played by the mucosa in bronchoconstriction. Bull Physiopathol Respir 1972;8:545-57. 